\title{
DE FUNCTIE VAN DE ACCOUNTANT IN HET KADER VAN DE PENSIOEN _ EN SPAARFONDSENWET
}

\author{
door C. P. A. Bakker
}

In het nummer van januari 1956 van dit blad is van de hand van de heer W. G. Brugge een artikel opgenomen onder de titel: De functie van de accountant en actuaris in het kader van de Pensioen- en Spaarfondsenwet.

Het heeft mij bevreemd dat nadien niemand meer zijn mening over dit vraagstuk heeft gepubliceerd en wel omdat vele accountants bij de hier aan de orde gestelde problemen betrokken zijn, terwijl daarover allerminst overeenstemming bestaat.

In het hierna volgende wil ik een poging doen om de waardevolle bijdrage van de heer Brugge op enkele punten aan te vullen en - waar het m.i. onjuistheden betreft - te verbeteren.

De moeilijkheid dat artikel 10 lid 2 van de wet spreekt van een actuarieel verslag en van een door de accountant gecontroleerd verslag is opgelost door de uitvoeringsbepalingen van de wet $t$.w. het Koninklijk Besluit van 17 december 1953 S. 574 en de daarop gegronde gemeenschappelijke beschikking van de Staatssecretaris van Sociale Zaken van 19 december 1953 en van de minister van Justitie van 28 december 1953. In het kort gezegd komt dit hier op neer: de bekende staten vormen het wettelijk verslag.

Ten aanzien van de waardering der verplichtingen merkt de heer Brugge op:

..Daar is allereerst de sterftekans, welke hier een belangrijke rol speelt. De bii de berekening gehanteerde sterftetafels zijn gebaseerd op veel grotere groepen dan de beperkte groep deelnemers van het pensioenfonds. Een afwijkende leeftijdsopbouw van de laatste kan een belangrijk verschil met de theoretische sterftekans opleveren." Het laatste is niet juist. De leeftijdsopbouw van een groep deelnemers heeft met sterftekansen niets te maken. Hier worden twee zaken verward:

1e. de waarschijnlijkheid dat de werkelijke sterfte zal afwijken van die. welke on grond van de sterftetafels wordt gecalculeerd. (Het universum dat de grondslag voor de sterftetafel vormde bestaat niet meer!)

2e. de waarschijnlijkheid dat de afwijking bij een kleine groep groter zal zijn dan bij een grote groep.

Misschien heeft de heer Brugge ook gedacht aan de mogelijkheid dat bij een groot pensioenfonds de actuaris voor de berekening van de baten geen gebruik maakt van individuele premies doch van een doorsneepremie. Dit is echter een af zonderlijke factor, welke naast de sterftekansen staat.

Dat de rekenrentevoet bij de waardering der verplichtingen van belang is kan ik geheel onderschrijven. Met de door de heer Brugge genoemde derde onzekere factor in de berekening n.l. de toekomstige loonsverhogingen, ben $i \mathrm{k}$ het niet eens. Mogelijke toekomstige loonsverhogingen worden slechts bij uitzondering in de berekening verdisconteerd. De Pensioen- en Spaarfondsenwet eist dit ook niet. Het is een geheel andere kwestie of een werkgever er goed aan doet pensioentoezeggingen te koppelen aan de grootte van het salaris over de laatste vijf dienstjaren. Het hieruit door algemene loonsverhogingen voortspruitende risico wordt in de praktijk echter opgevangen door beperkende maatregelen in het pensioenreglement.

Het belangrijkste punt dat de heer Brugge aan de orde heeft gesteld is dt 
vraag of de accountant een goedkeurende verklaring kan afgeven over een boekjaar, aan het einde waarvan de wiskundige reserve niet is berekend. Volgens het Bestuur van het Nederlands Instituut van Accountants mag een accountant in dat geval, behoudens een enkele uitzondering, geen goedkeurende verklaring geven, omdat geen zekerheid bestaat omtrent de belangrijkste post van de jaarrekening. Met de strekking van deze opvatting kan ik mij verenigen, doch dit behoeft m.i. niet in te houden, dat de berekening van de wiskundige reserve ook elk jaar door een actuaris geschiedt. Hierbij zij vooropgesteld, dat de berekening van de wiskundige reserve geen doel op zich is, doch slechts een middel om na te gaan of de middelen van het fonds toereikend zijn voor de aangegane verplichtingen. (In dit verband dient on der "middelen" te worden verstaan: de bezittingen verminderd met de schulden, andere dan die voortspruitend uit de pensioenverplichtingen.) Men hoede zich ervoor de betekenis van de berekening van de wiskundige reserve te overschatten. De werkelijkheid zal altijd een ander beeld geven dan deze berekening. Door het aanbrengen van veiligheidsmarges in de grondslagen zorgt de actuaris ervoor, dat een berekening op een later tijdstip met een zeer hoge graad van waarschijnlijkheid een overschot zal aanwijzen.

Daarbij komt nog, dat naar het oordeel van de Verzekeringskamer ${ }^{\star}$ ) elk pensioen fonds behalve over een op veilige grondslagen berekende wiskundige reserve moet beschikken over een extra reserve. Deze extra reserve moet men zien als een verlengstuk van de wiskundige reserve voor de niet-calculeerbare verliezen.

Het is derhalve onjuist te stellen, dat de wiskundige reserve de zuiverste voorstelling geeft van de pensioenverplichtingen.

De extra reserve wordt in de praktijk gevormd door de overschotten, welke ontstaan als gevolg van de veiligheidsmaraes in de berekening van de wiskundige reserve, en door bijzondere baten. In dit verband zou ik willen wijzen op de overeenkomst tussen de positie van een pensioenfonds en die van een spaarbank. In beide gevallen domineert het crediteurenbelang. Voor de crediteuren is het primair van belang, dat het vermogen voldoende is. Voor een pensioenfonds is de betekenis van de rentabiliteit van dit vermogen hiervan niet te scheiden, doch door een verantwoorde reserveberekening wordt hierin a.h.w. automatisch voorzien.

De vraag is nu of de accountant in een jaar, aan het einde waarvan de wiskundige reserve niet door een actuaris is berekend, op goede gronden tot de overtuiging kan komen. dat de aanwezige middelen toereikend zijn voor de aangegane verplichtingen.

Naar mijn mening kan deze vraag in vele gevallen bevestigend worden beantwoord. Hierbij wordt de accountant door de wet geholpen. Elk pensioenfonds behoeft overeenkomstiq artikel 4 van de Pensioen- en Spaarfond senwet de goedkeuring van de Minister van Sociale Zaken en Volksgezondheid. Artikel 10, 1e lid van deze wet zegt:

,1. Overdracht of herverzekering van het uit de aangegane verplichtingen voortspruitende risico behoeft bij een pensioenfonds niet plaats te hebben, indien:

$1^{\circ}$. het fonds werkt volgens een actuariële en bedrijfstechnische nota betreffende het te voeren beleid, waarbij de financiële opzet en de grondslagen, waarop het rust, gemotiveerd omschreven zijn en

\#) zie jaarverslag 1954 van de Verzekeringskamer - blz. 56.

m a b blz. 210 
waartegen de Verzekeringskamer verklaard heeft geen bezwaar te hebben;

$2^{\circ}$. door of vanwege het bestuur van het fonds ten genoegen van de Verzekeringskamer aangetoond wordt, dat het fonds voldoende draagvlak bezit voor het zelfstandig dragen van het risico."

Het $2 \mathrm{e}$ punt is van bijzonder belang want voldoende draagvlak bezitten voor het zelfstandig dragen van het risico betekent praktisch niets anders dan dat de kans op sterfteverliezen binnen redelijke grenzen ligt.

Vóór het Bestuur van het Nederlands Instituut van Accountants zijn standpunt bekend maakte, was in de praktijk reeds een systeem gegroeid, dat de accountant voldoende inzicht verschafte om de jaarrekening van een pensioenfonds te tekenen zonder berekening van de wiskundige reserve door een actuaris. Dit systeem bestond in het aanbrengen van correcties op een actuariëel berekende wiskundige reserve volgens onderstaand schema totdat opnieuw een actuariële berekening nodig werd geoordeeld.

\section{SCHEMA VAN BEREKENING}

Actuariëel berekende reserve aan het begin van het jaar ... $f$

bij: $1 / 2$ jaar intrest volgens de rekenrentevoet ..................

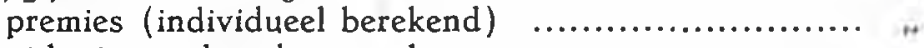

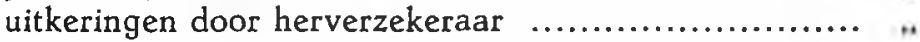

af: pensioenen $\ldots \ldots \ldots \ldots \ldots \ldots \ldots \ldots \ldots \ldots \ldots, f$

premies herverzekering .................,

bij: $1 / 2$ jaar intrest volgens de rekenrentevoet ...............

Gecorrigeerde wiskundige reserve aan het eind van het jaar

Of deze benaderde wiskundige reserve bruikbaar is hangt af van de richting en de omvang van de fout, welke door de benadering wordt veroorzaakt. Reeds een oppervlakkige bestudering van het schema doet zien, dat de afwijking gezocht moet worden bij de resultaten ten aanzien van grondslag sterfte. Hierboven is met andere woorden reeds gezegd dat de actuaris bij zijn berekeningen uit veiligheidsoverwegingen de kansen op sterftewinst onderschat en de kansen op sterfteverlies overschat. Dit betekent dat in het algemeen de afwijking tendeert naar een te hoog opgenomen benaderde wiskundige reserve. Het niet tot uitdrukking brengen van sterftewinsten is niet gevaarlijk. Dit punt laat ik daarom rusten. Het niet tot uitdrukking brengen van niet door sterftewinst gecompenseerde sterfteverliezen kan echter wel gevaar opleveren. Deze verliezen vragen daarom een nader onderzoek. Dit onderzoek lijkt veel op het onderzoek in het industriëel bedrijf, waar de accountant eerst de normen beoordeelt en daarna de afwijkingen tussen vooren nacalculatie beziet. Bij een pensioenfonds beschikt de accountant in de eerste plaats over de laatste door de actuaris opgemaakte staat 17 , waarin tegenover elkaar worden gesteld uitkomst en verwachting ten aanzien van de grondslag sterfte. Deze staat geeft de accountant voor de eerstkomende 
jaren een globale indruk van het aantal sterfgevallen, dat hij kan verwachten,waaraan hij het werkelijke aantal sterfgevallen kan toetsen. Vermoedt de accountant op grond van deze vergelijking een sterfteverlies, dan is een critische beschouwing van de individuele gevallen nodig. Hierop kan ik niet te diep ingaan. Ik volsta met op te merken, dat:

a. bij overlijden van een oudere deelnemer de reserve voor ouderdoms - en weduwe- en wezenpensioen gelijk of zelfs hoger kan zijn dan de benodigde reserve voor een ingegaan weduwe- en wezenpensioen;

b. bij een grotere sterfte dan verwacht mocht worden tegenover de benodigde reserve voor de ingegane weduwe- en wezenpensioenen altijd een vrijvallen van de reserve voor ouderdomspensioen staat.

Met behulp van bekende individuele (of collectieve) tarieven van levensverzekeringmaatschappijen kan de accountant zich dan verder een beeld van het sterfteverlies vormen.

Twijfelt de accountant daarna nog, dan kan hij altijd nog het advies van een actuaris of levensverzekeringmaatschappij vragen. De praktijk wijst uit, dat dit slechts bij uitzondering het geval zal behoeven te zijn.

De consequenties van de toepassing van het hierboven beschreven systeem zijn belangrijk n.l. een besparing van kosten. In een jaar, waarin geen wiskundige reserve wordt berekend behoeven geen gegevens voor de actuaris te worden verzameld, de accountant behoeft deze gegevens niet te controleren, zodat zowel op de kosten van de actuaris, van het fonds zelf (of van de werkgever) als op de kosten van de accountant een besparing ontstaat. De wet laat toe dit systeem vier achtereenvolgende jaren toe te passen. Van geval tot geval zal de accountant in overleg met de actuaris en het bestuur van het fonds moeten nagaan of en in hoeverre hij van die mogelijkheid gebruik zal maken.

Het voorgaande voert mij tot de volgende conclusie:

De accountant kan in vele gevallen, nadat de wiskundige reserve door een actuaris is berekend, gedurende enkele jaren zonder of met geringe actuariële hulp op goede gronden tot de overtuiging komen, dat voldoende middelen tot dekking van de pensioenverplichtingen aanwezig zijn en mitsdien de jaarrekening zonder voorbehoud tekenen.

Teneinde misverstand te voorkomen wil ik er nog op wijzen, dat een aldus gecorrigeerde wiskundige reserve niet mag worden gebruikt bij het invullen van de officiële staten. De officiële staten schrijven voor, dat in de jaren, waarin de wiskundige reserve niet door een actuaris is berekend het saldo van de rekening van lasten en baten als een afzonderlijke post naar de balans moet worden overgebracht. De aldus overgebrachte saldi stellen in de balans geen overschotten of tekorten voor, doch correcties op de ongewijzigd overgenomen (laatste) door een actuaris berekende wiskundige reserve. $\mathrm{Bij}$ de Verzekeringskamer kan dit geen misverstand veroorzaken. Ten aanzien van het verslag, dat het fonds aan de deelnemers verstrekt, geldt dit voorschrift niet. Daarin kan zonder bezwaar een gecorrigeerde wiskundige reserve worden opgenomen. In de praktijk ziet men ook wel dat in deze verslagen een post onder de naam: ,Vermogen tot dekking van de pensioenverplichtingen" wordt opgenomen, onder welke post dan zowel de al of niet gecorrigeerde wiskundige reserve als de extra reserve schuil gaat. Er is echter voorgeschreven, dat het fonds dan twee exemplaren van het verslag voor de deelnemers bij de Verzekeringskamer moet indienen. 
De accountant kan in sommige gevallen nog verder gaan. Er zijn b.v. verschillende kleinere fondsen, welke uitsluitend ouderdomspensioen in uitzicht stellen en waarbij het berekenen van de wiskundige reserve bestaat in het berekenen van de contante waarde van de bruto koopsommen, welke op de pensioendata bij een levensverzekeringmaatschappij moeten worden gestort. In deze gevallen is de inschakeling van een actuaris niet nodig, omdat de accountant deze berekeningen zelf kan maken.

Met het bovenstaande heb ik slechts een indruk willen geven van mogelijkheden omtrent welke verschil van mening bestaat. Het vraagstuk heeft zo veel facetten en de praktijk is zo veelsoortig, dat behandeling in een tijdschriftartikel noodzakelijk enige beperking meebrengt. Ik spreek de hoop uit, dat thans ook anderen hun mening zullen bekend maken. 